FACTA UNIVERSITATIS

Series: Physical Education and Sport, Vol. 18, No 2, 2020, pp. 311 - 322

https://doi.org/10.22190/FUPES200515029C

Research article

\title{
THE RELATIONSHIP BETWEEN BREAKFAST CONSUMPTION AND BASKETBALL SHOOTING PERFORMANCE
}

UDC 613.2:796

\author{
Dimitrije Čabarkapa ${ }^{1}$, Andrew C. Fry ${ }^{1}$, \\ Michael A. Deane ${ }^{2}$, Jeremy D. Akers ${ }^{3}$
}

${ }^{1}$ Jayhawk Athletic Performance Laboratory, University of Kansas, Lawrence, United States ${ }^{2}$ James Madison University, James Madison University Athletics, Harrisonburg, United States

${ }^{3}$ James Madison University, Department of Health Professions, Harrisonburg, United States

\begin{abstract}
The purpose of this study is to explore a possible relationship between breakfast consumption and basketball shooting performance. Eighteen male subjects (height $=191.5 \pm 10.1 \mathrm{~cm}$, mass $=93.8 \pm 12.1 \mathrm{~kg}$, age $=27.5 \pm 10.6$ years) with considerable amount of basketball playing experience were divided into two groups, with $(B F)$ and without (No-BF) four-day breakfast consumption in a threeweek cross-over study design. Subjects completed free throw, 2-point, and 3-point shooting drills on the fourth day of each week. Food intake records were collected during each treatment phase. Paired sample t-tests were used to examine the difference in basketball shooting performance (free throw, 2-point, and 3-point drills) and dietary intake patterns (calories, carbohydrates, proteins, and fats) between BF and No-BF testing weeks. Cohen's D effect sizes were calculated to determine the magnitude of the breakfast consumption as an experimental factor. The average amount of calories, carbohydrates, proteins, and fats that the subjects consumed during the breakfast omission week was significantly lower when compared to the breakfast consumption week. Even though the overall basketball shooting performance was improved during the breakfast consumption week, only the average free throw shooting accuracy revealed statistically significant results. However, the effect sizes for almost all the dependent variables exhibited small to moderate magnitudes. Considering that basketball players are always looking for ways to improve their shooting performance, a well-balanced diet with habitual breakfast consumption may be a beneficial method for individual and team performance enhancement, which can ultimately lead to increased chances of a successful game outcome.
\end{abstract}

Key words: Sport, Performance, Accuracy, Nutrition, Fatigue

Received June 15, 2020 / Accepted August 31, 2020

Corresponding author: Dimitrije Čabarkapa

Jayhawk Athletic Performance Laboratory, University of Kansas, 1301 Sunnyside Avenue Lawrence, Kansas, United States

Phone: + 785-864-5552• E-mail: dcabarkapa@ku.edu 


\section{INTRODUCTION}

For a long time, breakfast has been considered one of the most important meals of the day (Mahoney, Taylor, Kanarek, \& Samuel, 2005; Affenito, 2007; O'Neil et al., 2014; Clayton \& James, 2016). It is defined as a meal that breaks an overnight fast and it should be optimally consumed within two to three hours from waking up (O'Neil et al., 2014). Previous research suggested that the energy contribution of breakfast to the entire daily calorie intake should be approximately 20-35\% (O'Neal et al., 2014). Interestingly, besides having caloric value similar to all other main meals consumed during the day, breakfast consumption has been associated with improvements in the overall diet quality (Affenito, 2007; O'Neal et al., 2014). It is recommended that a well-balanced and optimally prepared breakfast should contain all three major macronutrients with greater emphasis placed on featuring rich complex carbohydrate sources (O’Neal et al., 2014). Mahoney et al. (2005) findings further support previously mentioned literature while also highlighting that adding protein and fiber-rich food items may additionally contribute to prolonged energy supply.

Frequently, when we think about sports performance enhancement, we place the main emphasis on the development of physiological characteristics and commonly disregard the existent cognitive influence. Speed of perception, response time, balance, coordination, selective attention, and visuospatial orientation are some cognitive components that can play a potential role in determining the capability of an athlete to compete at a specific level of competition (Parlić et al., 2018). Even though more work needs to be done in addressing cognitive improvements of various sport-specific tasks, there is a considerable amount of research supporting a strong relationship between breakfast consumption and cognitive performance quantified by improvements in academic performance (Mahoney et al., 2005; Hoyland, Dye, \& Lawton, 2009; Cooper, Bandelow, \& Nevill, 2011; Copper, Cooper, Bandelow, Nute, Morris, \& Nevill, 2012; O’Neil et al., 2014). Cooper and colleagues (2011) found that breakfast consumption enhanced cognitive function when compared to breakfast omission. Besides the self-reported increase in energy levels and a decrease in fatigue perception, significant improvements in the accuracy of cognitive tests such as the visual search test and Stroop test were observed for subjects assigned to ad libitum breakfast consumption trials (Cooper et al., 2011). Similar findings emerge in a follow-up study conducted on adolescent school children denoting that breakfast with a low glycemic index was the most beneficial for improvements in the accuracy of cognitive ability tests when compared to breakfast with a high glycemic index and breakfast omission (Cooper et al., 2012). To couple with previous research findings, Mahoney et al. (2005) found that together with improvements in standardized cognitive test scores, breakfast consumption can be highly beneficial for strengthening performance on complex visual tasks. In one of the studies conducted on high school children, researchers found that visuospatial performance following breakfast consumption significantly improved when compared to breakfast omission (Widenhorn-Müller, Hille, Klenk, \& Weiland, 2008). So, considering that breakfast consumption can significantly improve cognitive abilities, athletes participating in various sporting events might benefit from well-balanced and regular breakfast consumption. Alongside cognitive performance improvements, it is important to reflect on a decent quantity of research projects addressing the positive relationship between breakfast consumption and positive mood states (Benton \& Parker, 1998; WidenhornMüller et al., 2008; Veasey, Haskell-Ramsay, Kennedy, Tiplady, \& Stevenson, 2015). The 
inability of athletes to achieve optimal mood states may have a negative impact on their overall well-being which can further diminish peak athletic performance capabilities. Hence, considering that basketball is a complex game that besides optimal physical and physiological characteristics requires a considerable amount of cognitive involvement, breakfast consumption might be able to positively impact one of the key tasks that require high precision and accuracy - basketball shooting.

Another important factor that needs to be considered is the ability of breakfast to contribute to the overall calorie requirements necessary to support all energy needs. Previous research found that breakfast omission is associated with diminished daily calorie intake and reduction in exercise performance (Clayton, Barutcu, Machin, Stensel, \& James, 2015; Clayton \& James, 2016). If the exercise session is scheduled in the morning, the optimal time frame to consume breakfast is 1-4 hours before the start of exercise (Clayton \& James, 2016). The decreased amount of daily energy contribution caused by breakfast omission is unlikely to be compensated throughout the rest of the day which may have a negative effect on athletes looking to improve their performance (Clayton \& James, 2016). Basketball is a game based on repetitive stop-and-go motions, where considerable emphasis is placed on precision, accuracy, timing, and agility (Hoffman \& Maresh, 2000). Due to the nature of the game, the energy requirements are supplied from both aerobic and anaerobic sources which mainly include fat and carbohydrate dietary sources (Hoffman \& Maresh, 2000). Decreased fat consumption has been linked with impaired endurance performance (Venkatraman, Feng \& Pendergast, 2000) while also being associated with an overall decrease in calorie consumption (Horvath, Eagen, Fisher, Leddy \& Pendergast, 2013). Despite non-ergogenic benefits, pre-exercise fat consumption has been positively correlated with the reduction of carbohydrate utilization during exercise (Hargreaves, Hawley \& Jeukendrup, 2004). Although various styles of coaching can potentially influence the overall energy requirements, carbohydrates have been considered the main fuel source (Baar et al., 2013). However, unlike fat, carbohydrate energy sources are limited energy supplies and are highly dependent on the amount of glycogen stored in skeletal muscles and the liver. Previous research has shown that insufficient levels of muscle and liver glycogen content are associated with the quicker onset of fatigue and a decrease in the overall power output and work capacity (Clayton et al., 2015; Williams \& Rollo, 2015). While carbohydrates present the main energy source for various sports involving repetitive stopand-go motions such as basketball, we need to be aware of protein contribution to the overall energy production process, more from an energy support standpoint than as an energy supplier. To this point in time, there is a considerable amount of scientific literature addressing the importance of post-exercise protein consumption, while pre-exercise protein consumption stays vastly underexamined (Ormsbee, Bach, \& Baur, 2014). Based on current research knowledge, it is suggested that pre-exercise protein consumption can further improve glycogen synthesis and positively contribute to the overall energy metabolism during exercise (Ormsbee et al., 2014).

To analyze and find ways to optimize basketball performance, we should be aware of performance variables that are highly linked to the final game outcome. Researchers found that in both balanced and unbalanced games 2-point field goals were able to successfully discriminate between the winning and losing team (Lorenzo, Gómez, Ortega, Ibáñez, \& Sampaio, 2010). The winning team had a higher number of successful 2-point shooting attempts, while the overall shooting percentage was also superior when compared to the losing team (Lorenzo et al., 2010). This may lead us to assume that a 
winning ability could be related to greater fatigue resistance capabilities as the winning team had more offensive opportunities while also being able to achieve greater overall shooting accuracy. While the findings of Pojskić, Šeparović, \& Užičanin (2009) further support the importance of proficient 2-point shooting performance, they also indicate that successful shooting performance of bench players as well as those in the starting line-up can be a valuable factor in distinguishing between victorious and defeated teams. During elite basketball championship performance analysis, researchers found that 3-point percentage was one of the crucial determinants for the successful final game outcome (Trninić, Dizdar, \& Lukšić, 2002). Additionally, with similar methods of in-game analysis as mentioned in the previous studies, Csataljay, O'Donoghue, Hughes, \& Dancs (2009) found that the ability to secure free throw opportunities as well as a higher percentage of the successfully executed free throw of shots at the elite level of basketball competition was highly related to a greater final score of the game. Even though other factors can significantly impact the final game outcome such as turn-overs, steals, and offensive and defensive rebounds, based on the previously mentioned findings we can conclude that a successfully executed free throw, 2-point, and 3-point shots can serve as a solid predictor of the final game outcome (Ibáñez, Sampaio, Sáenz-López, Giménez, \& Janeira, 2003; Csataljay et al. 2009; Pojskić et al. 2009; Lorenzo et al., 2010; García, Ibáñez, De Santos, Leite, \& Sampaio, 2013).

Given the combination of all positive properties that breakfast may have on an individual, it is logical that basketball players consume a well-balanced breakfast on a daily basis to potentially increase their cognitive abilities and achieve optimal energy levels necessary for delayed onset of fatigue. To our knowledge, there are no research projects that observed the potential effect of breakfast consumption on basketball shooting performance.

Hence, the purpose of this study is to explore a possible relationship between breakfast consumption and basketball shooting performance, i.e., to explore if basketball shooting performance during the free throw, 2-point, and 3-point shooting drills can be augmented after breakfast consumption.

\section{METHODS}

\section{Subjects}

Eighteen male subjects (height $=191.5 \pm 10.1 \mathrm{~cm}$, mass $=93.8 \pm 12.1 \mathrm{~kg}$, age $=27.5 \pm 10.6$ years) with a considerable amount of basketball playing experience volunteered to participate in this research study. Subjects with any metabolic conditions or musculoskeletal injuries were excluded from participating in the study. All procedures performed in this research study were previously approved by the University's Institutional Review Board Committee.

\section{Diet Protocol}

The study was designed over three weeks starting with a pre-testing procedure. The first week was designed as a familiarization week where the subjects were not exposed to any intervention. The following week, the subjects were randomly assigned into two groups. Group 1 performed basketball shooting drills during the second week without breakfast 
consumption (No-BF), while Group 2 consumed breakfast (BF) for four consecutive days. During the third week of the intervention both groups switched treatment in a cross-over fashion. The subjects were asked to keep the same dietary pattern as their typical diet routine, including ad libitum eating patterns during meals. In addition, during the pre-testing week the subjects were individually trained on how to complete proper dietary records including meal timing, portion size, and type of preparation. The subjects were asked to record any kind of food and fluid consumed throughout the day. The breakfast that the subjects were instructed to consume was mostly composed of carbohydrates with smaller amounts of protein. The number of macronutrients provided during breakfast was specifically determined by the mass of the subject. Based on the International Society of Sport Nutrition guidelines, the breakfast that the subject was suggested to consume should be composed of $0.75-1.2 \mathrm{~g} / \mathrm{kg}$ of carbohydrates, $0.2-0.3 \mathrm{~g} / \mathrm{kg}$ of protein and a small percentage of fat content (Kreider et al., 2010). The subjects were provided with a detailed list of appropriate breakfast options that correspond to the previously mentioned criteria. Food intake records were collected each week on Thursday at the same individualized time. Three-day complete dietary records (Monday-Tuesday-Wednesday) were used for dietary analysis. The Nutritional Data System for Research (NDSR Software, Minneapolis, MN) was used to analyze all food intake records in order to obtain an estimate of calories and macronutrients that the subjects consumed during each day.

\section{Exercise Protocol}

Upon completion of a standardized warm-up procedure, the subjects were asked to complete three shooting drills that have been previously validated for shooting accuracy and fatigue (Pojskić, Šeparovic, \& Užičanin, 2011). The first drill was a free-throw shooting drill designed to test shooting accuracy without a fatigue component. The subjects were asked to shoot three sets of 10 free-throws $(4.57 \mathrm{~m})$ with a three-minute break between the sets. The two-point shooting drill was designed to test shooting accuracy with a fatigue component. The subjects were asked to shoot from five different spots marked with plastic cones for a period of 60 seconds. Each subject started at the cone numbered " 1 " under the basket and ran to the cone numbered " 2 " at the right corner where he received the ball from the passer. After the shot, the subject quickly returned to cone numbered " 1 " and ran to the cone numbered " 3 " at the " 45 -degree spot" where he received the ball from the passer again. All cones were positioned exactly five meters away from the rim (right corner, right 45 degrees, center, left 45 degrees and left corner). The pattern of the drills was repeating in both directions until the 60 seconds ran out. The three-point shooting drill was designed to test shooting accuracy with a fatigue component in the same pattern as the second drill, except the cones where the subjects are shooting from are positioned on a women's three-point line $(6.325 \mathrm{~m})$. A stopwatch was used to measure the time for the athlete to perform a specific basketball shooting drill. During every shooting drill a rebounder was present in order to preserve the subject's energy and assure an optimal focus directed towards the shooting motion. All shooting testing procedures were done on Thursday each week at the same individualized time. All subjects performed the shooting drills with a standardized size seven basketball. The research assistant recorded the number of shots made and attempted for each drill. In order to eliminate any kind of distraction potentially caused by other players on the court, the subjects performed the shooting drills individually. 


\section{Variables Sampled}

This study was focused on observing twelve dependent variables, four dietary intake and eight basketball shooting performance variables. The free throw average variable represents the average number of free-throw shots made during each set of 10 free-throws. The 2-point attempts and the 3-point attempts variables represent the overall number of 2-point and 3-point shots attempted during the 60 -second time period, respectively. In a similar manner, the 2-point shooting percentage and 3-point shooting percentage variables represent the shooting accuracy for 2-point and 3-point shooting drills expressed as a percentage of the total number of 2-point and 3-point shots attempted. The overall attempts variable represents a combined number of shots that each subject attempted during 2-point and 3-point shooting drills. The overall made shots variable represents the sum of made free-throw, 2-point, and 3-point shots, while the overall shooting percentage variable represents the shooting accuracy across all basketball shooting drills expressed as a percentage of the total number of attempted shots. The calories variable, expressed in kilocalories (kcal), represents the average amount of nutritional energy consumed, while the carbohydrate, protein, and fat variables, expressed in grams $(\mathrm{g})$, represent the average amount of each macronutrients consumed during each of the intervention periods.

\section{Statistical Analysis}

Paired sample t-tests were used to examine the difference in basketball shooting performance (free throw, 2-point, and 3-point drills) and dietary intake patterns (calories, carbohydrates, proteins, and fats) between BF and No-BF testing weeks. Cohen's D effect sizes were calculated to determine the magnitude of the breakfast consumption as an experimental factor. Due to the exploratory nature of this study, the statistical significance level was set to $\mathrm{p}<0.10$. Statistical analysis was conducted with the SPSS statistical package Version 25.0 (SPSS Inc. Chicago, IL, USA).

\section{RESULTS}

Mean values and standard deviations $(\mathrm{X} \pm \mathrm{SD}), \mathrm{p}$-values, and Cohen's D effect sizes for each of the basketball shooting performance and dietary intake variables are presented in Table 1. The only statistically significant difference in basketball shooting performance was observed for the free throw shooting accuracy. Despite noticeable differences in the accuracy and fatigue components of the 2-point and 3-point shooting drills, no other statistically significant differences in basketball shooting performance variables were observed. However, Cohen's D effect size magnitudes for all of the shooting performance variables examined in this study demonstrated small to moderate magnitudes, except for the 2-point shooting percentage. The average amount of calories, carbohydrates, proteins, and fats that the subjects consumed during the BF week was significantly greater when compared to the No-BF testing week. Based on Cohen's D effect sizes, the differences in dietary data-dependent variables between the BF and NoBF week demonstrated moderate to strong magnitudes. 
Table 1 Mean values and standard deviations $(\mathrm{X} \pm \mathrm{SD}), \mathrm{p}$-values, and Cohen's D effect sizes for dietary intakes and basketball shooting performance variables

\begin{tabular}{lrrrcc}
\hline Dependent variables & BF & \multicolumn{1}{c}{ No-BF } & p-value & Cohen's D \\
\hline Free throw average & $8.0 \pm$ & 1.4 & $7.3 \pm 1.9 *$ & 0.06 & 0.47 \\
2-point attempts & $11.2 \pm$ & 0.19 & $11.0 \pm 1.1$ & 0.26 & 0.31 \\
2-point shooting \% & $57.4 \pm 17.0$ & $55.9 \pm 21.3$ & 0.78 & 0.09 \\
3-point attempts & $9.7 \pm$ & \pm .7 & $9.5 \pm 1.0$ & 0.45 & 0.22 \\
3-point shooting \% & $47.9 \pm 20.8$ & $40.9 \pm 23.3$ & 0.43 & 0.34 \\
Overall attempts & $20.9 \pm 1.4$ & $20.5 \pm 2.0$ & 0.26 & 0.31 \\
Overall made shots & $35.1 \pm 7.2$ & $32.6 \pm 10.0$ & 0.19 & 0.35 \\
Overall shooting \% & $68.7 \pm 13.6$ & $64.0 \pm 18.3$ & 0.19 & 0.35 \\
Calories (kcal) & $2034.6 \pm 595.0$ & $1659.9 \pm 363.2 *$ & 0.02 & 0.63 \\
Carbohydrate (g) & $226.7 \pm 67.4$ & $186.5 \pm 54.4 *$ & 0.02 & 0.60 \\
Protein (g) & $101.1 \pm 37.3$ & $81.7 \pm 17.8 *$ & 0.03 & 0.52 \\
Fat (g) & $80.3 \pm 30.9$ & $63.6 \pm 18.7 *$ & 0.06 & 0.54 \\
\hline
\end{tabular}

Legend: BF-breakfast consumption testing week; No-BF-breakfast omission testing week; statistical significance set at the level $\mathrm{p}<0.10$.

\section{DISCUSSION}

To our knowledge this was the first study that examined the relationship between breakfast consumption and basketball shooting performance. Despite the considerable amount of research focused on emphasizing the importance of breakfast for optimal energy availability and cognitive functioning, there is a remaining gap in scientific literature addressing the relationship between breakfast consumption and sports performance. Based on the findings of this study we were able to observe a potential positive effect of breakfast on basketball shooting performance. While noticeable improvements were present for each of the shooting drills examined in this study during the BF testing week, only free throw shooting accuracy unveiled a statistically significant difference. Considering that previous research found that winning teams successfully performed more free throw shots compared to the opponent (Trninić el al., 2002; Ibáñez et al., 2003; Lorenzo et al., 2010), we may be able to assume that breakfast consumption can have a positive impact on the increased winning probability. This may be especially beneficial within the modern style of basketball play where the meaningful emphasis is placed on long-distance 3-point shots and 2-point scoring opportunities around the basket. Dribbling down the lane for a lay-up or a dunk opportunity seems like a more efficient way of scoring than shooting middistance 2-point shots. Besides the increase in the field goal scoring opportunity, this approach can greatly increase the chances of foul commitment by the defender and put the offensive player in the position to shoot more non-contested free throw shots as a high probability scoring opportunity. Thus, if breakfast consumption is capable of eliciting positive effects on free throw shooting performance through improvements in cognitive abilities and sustained fatigue resistance mechanisms, we may assume that the team will be in a better position to secure the successful game outcome.

Besides solely being focused on the interpretation of statistically significant results, we need to be aware of the effect sizes as an index used to quantify the practical significance of the research findings (Hojat \& Xu, 2004). When we refer to practical significance, we are mainly addressing how useful the results are in the real world, while 
statistical significance is mainly based on examining whether the outcome of the results is due to the chance or sampling variability (Kirk, 1996). In 2007, Atkinson emphasized the importance of practical significance, especially in the sport and exercise science field, while suggesting that inferences should be based more on an estimation of true effect sizes than solely on statistical significance. There are many examples in sport where small advancements in performance variables can be crucial for an athlete's success and may be able to determine the difference between a successful inferiorly qualified athlete or team. So, knowing that basketball is a game of percentages, moderate effect sizes observed for the majority of the basketball shooting drills examined in this study may lead us to assume that breakfast consumption could be a useful choice that athletes should habitually implement in order to optimize their basketball shooting accuracy and improve fatigue resistance. Based on our findings, basketball players were able to increase their 3point shooting percentage by approximately $7 \%$ during the BF week when compared to the No-BF testing week. If we take into account that a good 3-point shooting percentage is generally considered to fall within the 30-40\% range, improvements induced by breakfast consumption such as observed in this study may be able to serve as an effective contributor for achieving peak basketball shooting performance. Based on the previous research findings, besides 3-point shooting performance being one of the crucial factors for determining a successful game outcome (Ibáñez et al., 2003; Csataljay et al. 2009), Lorenzo and colleagues (2002) discovered that successful teams had an approximately 5\% greater 3point shooting percentage when compared to unsuccessful teams. Even though improvements in the 3-point shooting percentage was greater when compared to the 2-point shooting drill, the subjects were still able to maintain approximately $2 \%$ higher basketball shooting accuracy during the $\mathrm{BF}$ week when compared to the No-BF week. Hence, if improvements in shooting performance such as observed in this exploratory research study can be translated into a real game setting, we can conclude that regular consumption of well-balanced breakfast may have a positive relationship with the improvements in individual basketball shooting performance that would ultimately lead to the enhanced team winning probabilities.

Based on the daily dietary food records analysis, drastic statistically significant differences, as well as effect sizes, were observed for the overall daily calorie, carbohydrate, fat, and protein intakes between the BF and No-BF testing weeks. Our data is in agreement with previous research findings obtained from a cohort of recreationally active adult males suggesting that the overall energy intake was suppressed for approximately $19 \%$ during the breakfast omission trial (Clayton et al., 2015). When researchers examined the impact of breakfast omission on the overall daily calorie intake within a cohort of elementary school children, they found that students who skipped breakfast had an approximate 400 calory deficiency in their total daily energy consumption (Nicklas, Bao, Webber, \& Berenson, 1993). Furthermore, these individuals were also unable to make up for the difference in caloric intake throughout the day (Nicklas et al., 1993). Even though the subjects who participated in this exploratory research study were adult male basketball players, we were able to perceive a similar pattern of decline in the total daily energy consumption during the breakfast omission week as well as an inability to overcompensate for the missed energy intake opportunity. In one of the recent research studies, Nikić, Pedišić, Šatalić, Jakovljević, \& Venus (2014) found that the mean caloric intake of elite-level junior basketball players was significantly higher when compared to the non-athletic population. These findings are completely predictable when taking into account that supplementary caloric intakes are required to support additional physical activity requirements and delay the onset of fatigue. Thus, based on our findings, we 
may be able to assume that insufficient energy availability during the No-BF week induced with breakfast omission could be positively correlated with the decrease in the free throw, 2point, and 3-point basketball shooting performance.

Besides the overall caloric intake, Clayton and colleagues (2015) analyzed the total daily macronutrient energy contribution and found that subjects who regularly consumed a well-balanced breakfast had significantly higher carbohydrate, protein, and fat intakes. These findings are in complete agreement with our dietary data analysis. During the No$\mathrm{BF}$ testing week the subjects had a statistically significant decrease in all three macronutrients examined. Even though fat and protein sources play an important role in the overall energy metabolism, our focus should be mainly aimed at carbohydrates as the main energy source for stop-and-go sports, such as basketball (Hoffman \& Maresh, 2000; Baar et al., 2013). A considerable amount of previous research has shown that insufficient carbohydrate consumption is related to decreased glycogen synthesis, which ultimately leads to decrease in sports performance and quicker onset of fatigue (Balsom et al., 1999a; Balsom et al., 1999b; Clayton et al., 2015; Williams \& Rollo, 2015). Although muscle glycogen concentration was not examined in this exploratory study, a significant decrease in carbohydrate consumption was observed during the No-BF week. The overall number of shots attempted during the 2-point and 3-point shooting drills designed to test basketball shooting fatigue resistance did not demonstrate statistical significance; however, the effect sizes revealed moderate magnitudes. This may lead us to assume that breakfast may have a potential positive influence on the improvements in basketball shooting performance by delaying the onset of fatigue and allowing players to maintain their optimal shooting accuracy. In practical in-game settings, during close games having an opportunity to take an extra shot may significantly contribute to overall winning probability, especially if the shot is taken by a player with a decent shooting percentage. On the other hand, previous research indicates that the overall daily fat consumption is greater during breakfast omission (Ruxton \& Kirk, 1997). Our data does not agree with previously mentioned findings as the difference between the overall daily carbohydrate and fat intake during the BF week was almost identical when compared to the No-BF week. Even though both macronutrients declined in magnitude during the No-BF week, their proportion to the overall energy intake remained unchanged.

Considering that this was the first study that examined the effect of breakfast consumption on basketball shooting performance, certain limitations are present and should be addressed in future research studies. An inability to observe statistically significant differences in basketball shooting performance might be attributed to the narrow time period that the subjects were exposed to BF or No-BF testing trials and the level of fatigue induced by the shooting drills examined in this study. Further research should examine the effect of breakfast consumption/ omission throughout a longer time span and greater intensity fatiguing protocols which may magnify the positive underlying patterns observed in this research study. Also, further research should attempt to observe the effect of breakfast consumption/omission on in-game shooting performance as well as some of the other key performance variables such as turnovers, steals, and offensive and defensive rebounds. 


\section{CONCLUSIONS}

To our knowledge this is the first study that examined the relationship between breakfast consumption and basketball shooting performance. Based on our findings we can conclude that there is an underlying positive relationship between breakfast consumption and basketball shooting performance. Considering that basketball players are always looking for ways to improve their shooting performance, a well-balanced diet with habitual breakfast consumption may be a beneficial method for individual and team performance enhancement, which can ultimately lead to increased chances of a successful game outcome.

Acknowledgment: The authors would like to thank all the subjects that volunteered to participate in this research study as well as the University's Athletic Department for allowing us to use their sports facilities and equipment.

\section{REFERENCES}

Affenito, S.G. (2007). Breakfast: A missed opportunity. Journal of the Academy of Nutrition and Dietetics, 107(4), 565-569.

Atkinson, G. (2007). What's behind the numbers? Important decisions in judging practical significance. Sportscience, $11,12-16$.

Baar, K., Baker, L.B., Halson, S.L., Osterberg, K., Ransone, J., Spriet, L., et al. (2013). Nutrition and recovery needs of the basketball athlete. GSSI Basketball, 29-34.

Balsom, P.D., Wood, K., Olsson, P., \& Ekblom, B. (1999a). Carbohydrate intake and multiple sprint sports: with special reference to football (soccer). International Journal of Sports Medicine, 20(1), 48-52.

Balsom, P.D., Gaitanos, G.C., Söderlund, K., \& Ekblom, B. (1999b). High-intensity exercise and muscle glycogen availability in humans. Acta Physiologica Scandinavica, 165, 337-346.

Benton, D., \& Parker, P.Y. (1998). Breakfast, blood glucose, and cognition. The American Journal of Clinical Nutrition, 67(4), 772-778.

Cooper, S.B., Bandelow, S., \& Nevill, M.E. (2011). Breakfast consumption and cognitive function in adolescent schoolchildren. Physiology \& Behavior, 103(5), 431-439.

Cooper, S.B., Bandelow, S., Nute, M.L., Morris, J.G., \& Nevill, M.E. (2012). Breakfast glycaemic index and cognitive function in adolescent school children. British Journal of Nutrition, 107(12), 1823-1832.

Clayton, D.J., Barutcu, A., Machin, C., Stensel, D.J., \& James, L.J. (2015). Effect of breakfast omission on energy intake and evening exercise performance. Medicine \& Science in Sports \& exercise: Official Journal of the American College of Sports Medicine, 47(12), 2645-2652.

Clayton, D.J., \& James, L.J. (2016). The effect of breakfast on appetite regulation, energy balance and exercise performance. Proceedings of the Nutrition Society, 75(3), 319-327.

Csataljay, G., O’Donoghue, P., Hughes, M., \& Dancs, H. (2009). Performance indicators that distinguish winning and losing teams in basketball. International Journal of Performance Analysis in Sport, 9(1), 60-66.

García, J., Ibáñez, S.J., De Santos, R.M., Leite, N., \& Sampaio, J. (2013). Identifying basketball performance indicators in regular season and playoff games. Journal of Human Kinetics, 36(1), 161-168.

Hargreaves, M., Hawley, J.A., \& Jeukendrup A. (2004). Pre-exercise carbohydrate and fat ingestion: effects on metabolism and performance. Journal of Sport Sciences, 22(1), 31-38.

Hoffman, J.R., \& Maresh C.M. (2000). Physiology of basketball. In: W.E., Garrett, \& D.T. Kirkendall (Eds.), Exercise and Sport Science. (pp. 733-744). Philadelphia: Lippincott Williams \& Wilkins.

Hojat, M., \& Xu, G. (2004). A visitor's guide to effect sizes-statistical significance versus practical (clinical) importance of research findings. Advances in Health Sciences Education, 9(3), 241-249.

Horvath, P.J., Eagen, C.K., Fisher, N.M., Leddy, J.J., \& Pendergast D.R. (2000). The effects of varying dietary fat on performance and metabolism in trained male and female runners, Journal of the American College of Nutrition, 19(1), 52-60.

Hoyland, A., Dye, L., \& Lawton, C.L. (2009). A systematic review of the effect of breakfast on the cognitive performance of children and adolescents. Nutrition Research Reviews, 22(2), 220-243. 
Ibáñez, S.J., Sampaio, J., Sáenz-López, P., Giménez, J., \& Janeira, M.A. (2003). Game statistics discriminating the final outcome of junior world basketball championship matches (Portugal 1999). Journal of Human Movement Studies, 45(1), 1-20.

Kirk, R.E. (1996). Practical significance: A concept whose time has come. Educational and Psychological Measurement, 56(5), 746-759.

Kreider, R.B., Wilborn, C.D., Taylor, L., Campbell, B., Almada, A.L., Collins, R., et al. (2010). ISSN exercise \& sport nutrition review: Research \& recommendations. Journal of the International Society of Sports Nutrition, 7(1), 1-43

Lorenzo, A., Gómez, M.Á., Ortega, E., Ibáñez, S.J., \& Sampaio, J. (2010). Game related statistics which discriminate between winning and losing under-16 male basketball games. Journal of Sports Science and Medicine, 9, 664-668.

Mahoney, C.R., Taylor, H.A., Kanarek, R.B., \& Samuel, P. (2005). Effect of breakfast composition on cognitive processes in elementary school children. Physiology \& Behavior, 85(5), 635-645.

Nicklas, T.A., Bao, W., Webber, L.S., \& Berenson, G.S. (1993). Breakfast consumption affects adequacy of total daily intake in children. Journal of the American Dietetic Association, 93(8), 886-891.

Nikić, M., Pedišić, Ž., Šatalić, Z., Jakovljević, S., \& Venus, D. (2014). Adequacy of nutrient intakes in elite junior basketball players. International Journal of Sport Nutrition and Exercise Metabolism, 24(5), 516-523.

O'Neil, C.E., Byrd-Bredbenner, C., Hayes, D., Jana, L., Klinger, S.E., \& Stephenson-Martin, S. (2014). The role of breakfast in health: definition and criteria for a quality breakfast. Journal of the Academy of Nutrition and Dietetics, 114(12), S8-S26.

Ormsbee, M.J., Bach, C.W., \& Baur, D.A. (2014). Pre-exercise nutrition: the role of macronutrients, modified starches and supplements on metabolism and endurance performance. Nutrients, 6(5), 1782-1808.

Parlić, M., Ilić, A., Jakšić, V., Parlić, M., Makević, V., \& Milanović, S. (2018). The study of the age-related dynamics of the reaction time to visual stimuli in schoolchildren. Facta Universitatis Series Physical Education and Sport, 16(2), 337-346.

Pojskić, H., Šeparović, V., \& Užičanin, E. (2009). Differences between successful and unsuccessful basketball teams on the final Olympic tournament. Acta Kinesiologica, 3(2), 110-114.

Pojskić, H., Šeparovic, V., \& Užičanin, E. (2011). Reliability and factorial validity of basketball shooting accuracy tests. Sport Scientific And Practical Aspects, 8(1), 25-32.

Ruxton, C.H.S., \& Kirk, T.R. (1997). Breakfast: a review of associations with measures of dietary intake, physiology and biochemistry. British Journal of Nutrition, 78(2), 199-213.

Trninić, S., Dizdar, D., \& Lukšić, E. (2002). Differences between winning and defeated top quality basketball teams in final tournaments of European club championship. Collegium Antropologicum, 26(2), 521-531.

Veasey, R.C., Haskell-Ramsay, C.F., Kennedy, D.O., Tiplady, B., \& Stevenson, E.J. (2015). The effect of breakfast prior to morning exercise on cognitive performance, mood and appetite later in the day in habitually active women. Nutrients, 7(7), 5712-5732.

Venkatraman, J.T., Feng, X., \& Pendergast, D. (2001). Effects of dietary fat and endurance exercise on plasma cortisol, prostaglandin E2, enterferon-y and lipid peroxides in runners. Journal of the American College of Nutrition, 20(5), 529-536.

Widenhorn-Müller, K., Hille, K., Klenk, J., \& Weiland, U. (2008). Influence of having breakfast on cognitive performance and mood in 13-to 20-year-old high school students: results of a crossover trial. Pediatrics, 122(2), 279-284.

Williams, C., \& Rollo, I. (2015). Carbohydrate nutrition and team sport performance. Sports Medicine, 45(1), $13-22$.

\section{ODNOS IZMEĐU KONZUMACIJE DORUČKA I KOŠARKAŠKIH PERFORMANSI}

Svrha ovog istraživanja je da se istraži moguća povezanost između konzumacije doručka $i$ performansi u košarci. Osamnaest muških ispitanika (visina $=191.5 \pm 10.1 \mathrm{~cm}$, masa $=93.8 \pm 12.1 \mathrm{~kg}$, starost=27.5 \pm 10.6 godina) sa znatnim iskustvom igranja košarke podeljeno je u dve grupe, sa doručkom (BF) $i$ bez doručka (No-BF), tokom četiri dana nedeljno u okviru tronedeljnog istraživanja. Ispitanici su izvodili slobodna bacanja $i$ šuterske drilove za 2 i 3 poena, četvrtog dana tokom svake nedelje. Zapisi o unosu hrane prikupljani su tokom svake od faze istraživanja. T-test za uparene uzorke korišćen je za utvrđivanje razlike u performansama košarkaškog šutiranja 
(slobodna bacanja, šuterski drilovi za 2 i 3 poena) i obrascima ishrane (kalorije, ugljeni hidrati, proteini $i$ masti) između BF $i$ No-BF testiranja na nedeljnom nivou. Utvrđene su veličine Cohenovog $D$ efekta kako bi se odredila veličina konzumacije doručka kao eksperimentalnog faktora. Prosečna količina kalorija, ugljenih hidrata, proteina i masti koje su ispitanici konzumirali tokom nedelje bi izostavljali doručak bila je znatno niža u poređenju sa nedeljom u kojoj su konzumirali doručak. Iako su ukupne performanse šutiranja na koš poboljšane tokom nedelje konzumiranja doručka, samo su u prosečnim izvođenjima preciznih slobodnih bacanja utvrđeni statistički značajni rezultati. Međutim, veličina efekata za gotovo sve zavisne varijable pokazala je male do umerene veličine. S obzirom na to da košarkaši uvek traže načine za poboljšanje šuterskih performansi, dobro uravnotežena ishrana sa uobičajenom konzumacijom doručka može da predstavlja korisnu metodu za poboljšanje individualnih i timskih performansi, što u krajnjem može dovesti do povećanih šansi za uspešan ishod utakmice.

Ključne reči: sport, performanse, tačnost, ishrana, zamor 